\title{
RESULTS OF MEASUREMENTS IN THE 309 METER BORE HOLE AT BYRD STATION, ANTARGTICA
}

\author{
By Anthony J. Gow \\ (U.S. Army Cold Regions Research and Engineering Laboratory, Hanover, New Hampshire, \\ U.S.A.)
}

\begin{abstract}
Temperature, inclination, and closure have been measured in a $309 \mathrm{~m}$. deep drill hole at Byrd Station, Antarctica. The results of five series of measurements taken yearly since February ig 8 show that temperatures below $70 \mathrm{~m}$. have remained constant since December 1958 , that the closure rate has accelerated, and that the hole has undergone negligible inclination from the vertical. Anomalous temperatures in the upper levels of the drill hole are attributed to the steel casing that was permanently emplaced to a depth of $36 \mathrm{~m}$. during drilling in $1957-58$. A positive temperature gradient was observed in the casing, but negative gradients exist below the casing and a constant gradient profile is developed below $170 \mathrm{~m}$. Both ice motion and climatic changes at Byrd Station are thought to have contributed to the formation of the observed negative temperature gradients. Insignificant bending of the drill hole would imply negligible differential motion in the upper $300 \mathrm{~m}$. of the $2,400 \mathrm{~m}$. thick ice sheet at Byrd Station. The rate of hole closure has accelerated throughout the $4 \mathrm{yr}$. period of observations, except at the bottom of the drill hole, where the most recent measurements (February 1962) show that some constraint is now developing. Deformation rates throughout the drill hole are not proportional to some constant power of the stress; instead the value of the power has been found to increase with both increasing stress and time of application of stress. This behavior is attributed to some process of continuous deformational recrystallization of ice in the walls of the drill hole. A recoring of the deformed drill hole to investigate such effects is advocated.
\end{abstract}

RÉsumé. La température, l'inclinaison et la vitesse de fermeture ont été mesurées dans un trou de forage de $300 \mathrm{~m}$ de profondeur à Byrd Station dans l'Antarctique. Les résultats de 5 séries de mesures prises chaque année depuis février 1958 , montrent que les températures en-dessous de $70 \mathrm{~m}$ sont demeurées constantes depuis décembre 1958, que le taux de fermeture s'est accélèré et que le trou s'est incliné de façon négligeable par rapport à la verticale. Des températures anormales dans les niveaux supérieurs du trou sont attribuées au tubage qui a été mis en place de façon permanente à une profondeur de $36 \mathrm{~m}$, durant le forage en $1957-58$. Un gradient de température positif a été observé dans le tubage mais des gradients négatifs existent en-dessous et un profil à gradient constant se développe à partir de $170 \mathrm{~m}$. On pense que le mouvement de la glace et les variations climatiques à Byrd Station ont contribué à la formation des gradients de température négatifs observés. Une courbure insignifiante du trou indiquerait un mouvement différentiel négligeable dans les $300 \mathrm{~m}$ supérieurs, l'épaisseur de glace à Byrd Station étant de $2400 \mathrm{~m}$. Le taux de fermeture du trou s'est accélèré durant la période de 4 ans d'observation, à l'exception de la base du forage où les mesures les plus récentes (février I962) montrent qu'une contrainte se développe actuellement. Les taux de déformation le long du trou ne sont pas proportionnels à une puissance constante de la contrainte. Au lieu de cela, on a trouvé que la valeur de la puissance croissait à la fois avec une contrainte croissante et le temps d'application de cette contrainte. On attribue ce comportement à un processus de déformation continue par recristallisation de la glace sur les parois du trou. On préconise un nouveau forage du trou déformé pour étudier de tels effets.

Zusammenfassung. Temperatur, Neigung und Verengung eines $309 \mathrm{~m}$ tiefen Bohrloches in der Byrd Station, Antarktis, wurden gemessen. Die Ergebnisse von 5 Messerien, die jährlich seit Februar 1958 durchgeführt wurden, zeigen, dass die Temperaturen unterhalb $70 \mathrm{~m}$ seit Dezember $195^{8}$ konstant geblieben sind, dass die Geschwindigkeit der Verengung zunimmt, und dass das Loch nur eine vernachlässigbare Neigung gegenüber der Vertikalen erlitten hat. Anomale Temperaturen in den oberen Niveaus des Bohrlochs werden der Stahlverkleidung zugeschrieben, die während des Bohrens in den Jahren I $957-58$ ständig bis zu einer Tiefe von $36 \mathrm{~m}$ angebracht war. Ein positiver Temperaturgradient wurde in den verkleideten Teil des Bohrlochs beobachtet, darunter jedoch existieren negative Gradienten, und ein konstantes Profil hat sich unterhalb I $70 \mathrm{~m}$ entwickelt. Es wird angenommen, dass sowohl Eisbewegung als auch klimatische Anderungen an der Byrd Station zu der Bildung der beobachteten negativen Temperaturgradienten beigetragen haben. Die unbedeutende Verkrümmung des Bohrloches würde eine vernachlässigbare differentielle Bewegung in den oberen $300 \mathrm{~m}$ der $2400 \mathrm{~m}$ dicken Eisschicht in Byrd Station nahelegen. Die Geschwindigkeit der Verengung des Loches hat während der ganzen vierjährigen Beobachtungsperiode zugenommen, ausser am Boden des Bohrloches, wo die neuesten Messungen (Februar 1962) zeigen, dass sich dort jetzt eine gewisse Zwangsläufigkeit entwickelt. Die Deformationen entlang dem Bohrloch sind nicht proportional zu einer bestimmten Potenz der Spannung. Stattdessen wurde gefunden, dass der Exponent der Potenz sowohl mit wachsender Spannung als auch mit der Zeit seiner Einwirkung zunimmt. Dieses Verhalten wird einem gewissen Prozess von dauernder Deformations-Rekristallisation des Eises der Bohrlochwand zugeschrieben. Eine abermalige Bohrung des deformierten Bohrlochs zue Untersuchung solcher Effekte wird empfehlen. 


\section{INTRODUCTION}

During the austral summer of $1957^{-5} 5^{8}$ a deep hole was drilled to a depth of $309 \mathrm{~m}$. in the ice sheet at Byrd Station (lat. $80^{\circ} \mathrm{S}$., long. $120^{\circ} \mathrm{W}$.), West Antarctica. This deep core drilling formed part of the U.S. I.G.Y. glaciological program and was conducted by U.S.A. SIPRE (now CRREL). The principal aims of this project were to: (I) recover a continuous sequence of undisturbed cores on which to conduct profile studies of the physical and petrographic properties of snow, firn and ice in the upper levels of a high polar glacier, and (2) provide a deep hole for studying the temperature profile and the flow properties of ice in the same glacier. Drilling was accomplished with a Failing 1500 rotary well-drilling rig, specially modified for coring in ice, and using cold compressed air as the drilling fluid. Details of the actual drilling are to be found in the postoperational reports of Patenaude (1958) and Lange (in press). Preliminary results of core analyses and drill hole measurements have been published by Marshall and Gow (1958) and by Bender and Gow (196I). The temperature profile was measured at the end of drilling in February $195^{8}$, but it was not until December I $95^{8}$ approximately eleven months after the termination of drilling, that the bore hole was first fully instrumented for temperature, inclination and closure (Ragle and others, 1960). Further measurements were made in January I960, January I96I, and February 1962 and it is the purpose of this paper to present the results of these measurements of the past four years.

\section{Equipment AND Methods}

In December $195^{8}$ closures and temperatures were measured in a single trip down the drill hole. The use of a single-shot inclinometer in $195^{8}$ required a separate trip to each level of measurement in the drill hole, but in January 1960 , and in all subsequent measurements, the hole-gauging caliper, multiple-shot inclinometer and temperature probes (thermistors) were combined in a single instrument. This was attached to a steel-insulated triple conductor cable and lowered into the drill hole by means of a winch. Inclinations were measured as the cable was run down to the bottom of the hole, and closure and temperature measurements were made on the return trip. The winch and recording equipment were set up in an old disused undersnow laboratory and maintained at a temperature of approximately $-26^{\circ} \mathrm{C}$. The recording equipment consisted essentially of a Leeds and Northrup Wheatstone bridge and null indicator for measuring caliper and thermistor resistances, and a junction box for operating the inclinometer and for releasing the spring-loaded caliper at the bottom of the drill hole. The $195^{8}$ January summer surface was used as a datum level for all measurements, so as to ensure remeasurement at identical depths in the drill hole from one year to the next. This is particularly important for diameter measurements in the deeper parts of the drill hole, where closure is occurring relatively rapidly, and where an error of a meter or two in the depth would seriously effect the closure profile.

\section{Results}

\section{Temperature measurements}

Valid temperature data can be obtained during drilling if observations are made in the bottom of the drill hole each time the drill string is pulled. If temperatures are not measured until after the hole has been drilled out, as was the case at Byrd Station, then heat introduced during drilling can be expected to affect sensibly the temperature profile. At Byrd Station the principal source of "drill heat" was the compressed air used for removing drilling chips. Since the compressed air is circulated past the higher levels for a longer period than past the lower levels, the drill hole will warm up by a greater amount at the top than at the bottom. This "drill heat" will dissipate with time, but its influence is definitely reflected in the initial measurements of February 1958, when the temperature gradient was much steeper than observed in later profiles (see inset Fig. I). A similar effect was noted in the SIPRE drill hole at Site 2, 
Greenland in $1957-58$ (personal communication from B. Lyle Hansen). At Site 2 the difference in gradients at the end of ten months was nearly the same as that observed between the February $195^{8}$ and December $195^{8}$ profiles at Byrd Station. The Ioo ohm copper resistance thermometer (thermohm) used in February $195^{8}$ is known to furnish thoroughly reliable gradient data but the actual temperatures could be in error by as much as $0.2^{\circ} \mathrm{C}$. In

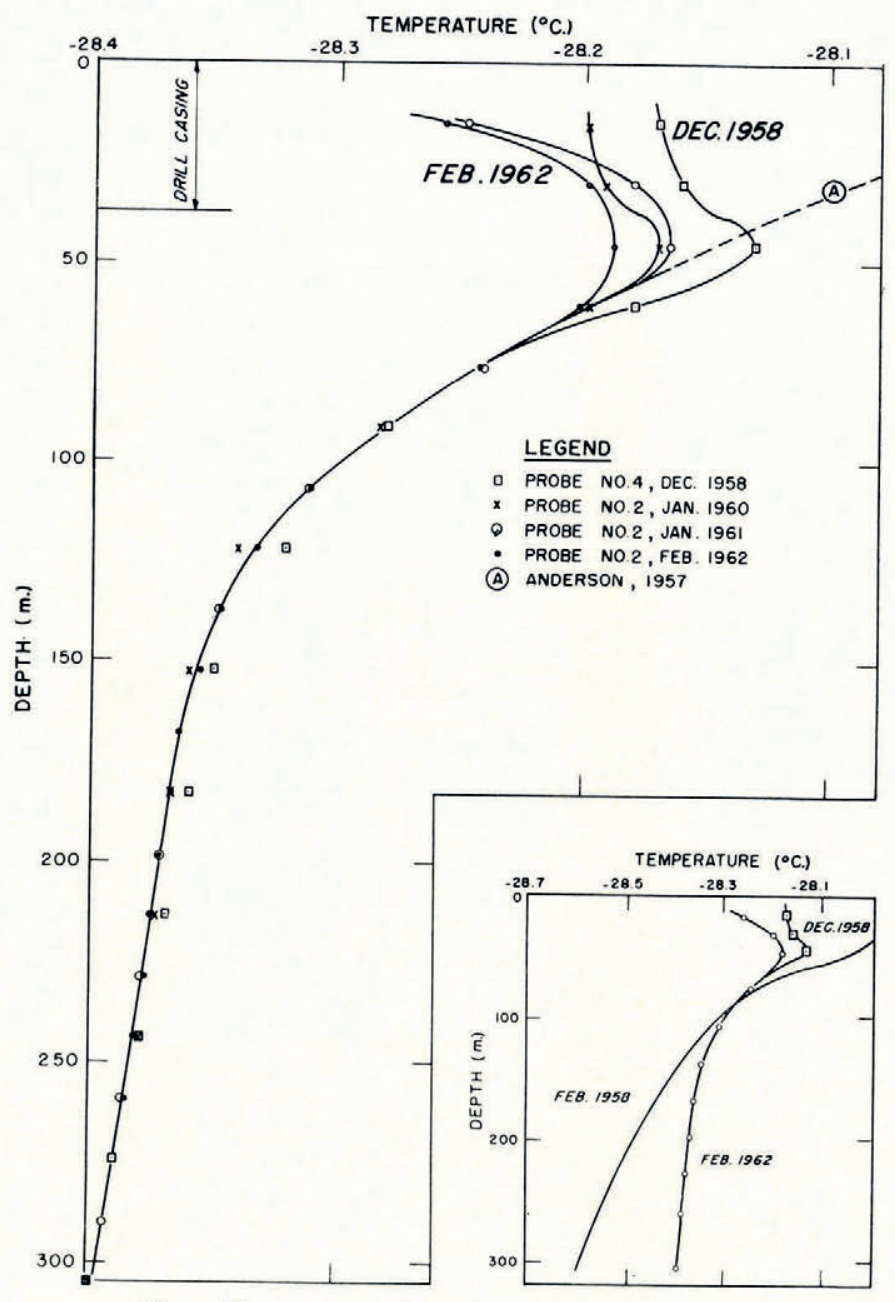

Fig. I. Temperature profiles, Byrd Station deep drill hole

December 1958 a highly sensitive thermistor-type probe (probe No. 4), capable of detecting temperature changes of $0.005^{\circ} \mathrm{C}$., was used for measuring temperatures in the drill hole. Two additional probes (No. 2 and No. 3) were used in January i 960 . Unfortunately, probes No. 3 and No. 4 were both lost down the hole during measurements in January I96r, but temperatures were obtained with probe No. 2, and the same thermistor was used for recording temperatures in January 1962. Results of all measurements with probes No. 2 and No. 4 are listed in Table I. These have all been corrected for instrumental errors, and are considered to be within $0 \cdot 02^{\circ} \mathrm{C}$. of the true temperatures. However, since the bridge resistances can be read to within $\pm \mathrm{I}$ ohm, equivalent to $\pm 0.00 \mathrm{I}^{\circ} \mathrm{C}$., with probe No. 2 the gradient data can 
Table I. Deep Hole Temperatures, Byrd Station, i $95^{8-62}$

\begin{tabular}{|c|c|c|c|c|c|}
\hline Depth & $\begin{array}{c}\text { Probe No. } 4 \\
\text { December } 1958\end{array}$ & $\begin{array}{l}\text { Probe No. } 4 \\
\text { January } 1960\end{array}$ & $\begin{array}{c}\text { Probe No. } 2 \\
\text { fanuary } 1960\end{array}$ & $\begin{array}{l}\text { Probe } \mathcal{N o} .2 \\
\text { Fanuary } 196{ }^{2}\end{array}$ & $\begin{array}{c}\text { Probe No. } 2 \\
\text { February } 1962\end{array}$ \\
\hline $\begin{array}{l}\mathrm{m} . \\
\mathrm{i} 5\end{array}$ & $\begin{array}{l}{ }^{\circ} \mathrm{C} . \\
-28.17\end{array}$ & $\begin{array}{l}\text { C. } \\
-28 \cdot 19\end{array}$ & $\begin{array}{c}\text { C. } \\
-28 \cdot 199\end{array}$ & $-28 \cdot 248$ & $-28 \cdot 257$ \\
\hline 31 & $\begin{array}{l}-28 \cdot 16 \\
-28 \cdot 1\end{array}$ & $-28 \cdot 17$ & $-28 \cdot 193$ & $-28 \cdot 18 \mathrm{I}$ & $-28 \cdot 199$ \\
\hline 46 & $-28 \cdot 13$ & $-28 \cdot 17$ & $-28 \cdot 171$ & $-28 \cdot 166$ & $-28 \cdot 189$ \\
\hline $\begin{array}{l}6 \mathrm{I} \\
76\end{array}$ & $-28 \cdot 18$ & $-28 \cdot 20$ & $-28 \cdot 201$ & $-28 \cdot 240$ & $\begin{array}{l}-28 \cdot 202 \\
-28 \cdot 242\end{array}$ \\
\hline $\begin{array}{r}91 \\
\text { I } 06\end{array}$ & $-28 \cdot 28$ & $-28 \cdot 29$ & $-28 \cdot 283$ & $-28 \cdot 3 \mathrm{II}$ & $\begin{array}{l}-28 \cdot 281 \\
-28 \cdot 310\end{array}$ \\
\hline I 22 & $-28 \cdot 32$ & $-28 \cdot 34$ & $-28 \cdot 340$ & - 8.048 & $-28 \cdot 33^{2}$ \\
\hline $\begin{array}{l}137 \\
152\end{array}$ & $-28 \cdot 35$ & $-28 \cdot 35$ & $-28 \cdot 360$ & $-20 \cdot 340$ & $\begin{array}{l}-28 \cdot 347 \\
-28 \cdot 356\end{array}$ \\
\hline $\begin{array}{l}168 \\
183\end{array}$ & & & & $-28 \cdot 365$ & $-28 \cdot 364$ \\
\hline $\begin{array}{l}183 \\
198\end{array}$ & $-28 \cdot 36$ & $-28 \cdot 36$ & $-28 \cdot 368$ & $-28 \cdot 372$ & $\begin{array}{l}-28 \cdot 368 \\
-28 \cdot 372\end{array}$ \\
\hline $\begin{array}{l}213 \\
228\end{array}$ & $-28 \cdot 37$ & $-28 \cdot 3^{8}$ & $-28 \cdot 374$ & $-28 \cdot 379$ & $\begin{array}{l}-28 \cdot 376 \\
-28 \cdot 37^{8}\end{array}$ \\
\hline $\begin{array}{l}244 \\
259\end{array}$ & $-28 \cdot 3^{8}$ & $-28 \cdot 39$ & $-28 \cdot 3^{8 I}$ & $-28 \cdot 3^{87}$ & $\begin{array}{l}-28 \cdot 382 \\
-28 \cdot 3^{86}\end{array}$ \\
\hline $\begin{array}{l}274 \\
289\end{array}$ & $-28 \cdot 39$ & $-28 \cdot 39$ & $-28 \cdot 39^{\circ}$ & $-28 \cdot 394$ & \\
\hline 305 & $-28 \cdot 4^{\circ}$ & $-28 \cdot 39$ & $-28 \cdot 404$ & & \\
\hline
\end{tabular}

be determined even more precisely. For this reason the probe No. 2 temperatures in Table I are given to the nearest millidegree. A depth-temperature curve for data from probe No. 2 is given in Figure $\mathrm{I}$; values obtained with probe No. 4 in December $195^{8}$ are also plotted in the same figure. These results show that the temperature profile below $70 \mathrm{~m}$. has remained virtually unchanged since December 1958. Above $70 \mathrm{~m}$., however, the temperatures have fluctuated. This is due in part at least to the existence of steel casing in the uppermost layers of permeable snow. This casing was set to a depth of $36 \mathrm{~m}$. during drilling in $1957-58$ to prevent loss of circulation of compressed air into the surrounding snow. The effects of conduction and convection in this region of the drill hole are difficult to evaluate at this stage. They could, perhaps, be profitably investigated in a moderately deep (say $60 \mathrm{~m}$.) uncased drill hole, but it is interesting to note that there has been a small but progressive decrease in temperatures in the cased portion of the drill hole since 1958. This may reflect a trend toward decreasing surface temperatures at Byrd Station over the past few years. Nevertheless, it would appear that whatever disturbances exist in the upper levels of the drill hole, these are exerting a negligible effect on the temperature profile below $70 \mathrm{~m}$. Further evidence of this stability at depth is indicated by the observation that the thermistors invariably equilibrated in a matter of minutes, and thereafter fluctuated by less than $0.002^{\circ} \mathrm{C}$., even when suspended at the same depth for several days. This would certainly indicate minimal convectional movement of air below $70 \mathrm{~m}$.

Negative temperature gradients (temperatures decreasing with depth) exist at all depths below $45 \mathrm{~m}$. in the drill hole, and a constant-gradient profile is developed below I 70 $\mathrm{m}$. The existence of a positive gradient in the upper $45 \mathrm{~m}$. of the drill hole seems anomalous, as snow temperature measurements at Byrd Station over the past five years have revealed negative gradients below about $15 \mathrm{~m}$. The fact that a negative gradient does not develop until just below the bottom of the casing would certainly suggest that the casing itself is in some way responsible for this anomalous increase in temperature down to $45 \mathrm{~m}$. Interestingly enough, no such anomaly was observed in the $400 \mathrm{~m}$. hole at Site 2 Greenland, where temperatures in the casing were found to agree very closely with those recorded in nearby hand-drilled auger holes (personal communication from B. Lyle Hansen). It should be noted, however, that the casing at Byrd Station was extended an additional $5 \mathrm{~m}$. above the snow surface in February I958, to ensure relocating the drill hole in the event of its anticipated burial under drifting snow. This exposed section of casing would seem to be the most likely cause of the anomalous 
air temperatures measured in the casing. For temperatures measured in summer, the casing appears to permit a positive temperature gradient to propagate down the entire length of casing and just beyond to a depth of $45 \mathrm{~m}$., approximately three times the depth to which positive temperature gradients have been observed to persist in undisturbed snow at Byrd Station. Presumably, a somewhat different profile would develop in the casing during winter but this has not been investigated. As indicated in Figure $\mathrm{I}$ the drill hole profile at $70 \mathrm{~m}$. could be extended in a reasonably smooth curve to intersect the temperature of $-28 \cdot \mathrm{I}^{\circ} \mathrm{C}$. measured by Anderson (1958) at a depth of $3 \mathrm{I} \mathrm{m}$. If extrapolated further, this same curve would yield a temperature of $-28 \cdot 0^{\circ} \mathrm{C}$. at about $15 \mathrm{~m}$., which compares favorably with the $-28 \cdot 00^{\circ} \mathrm{C}$. $\pm 0.05^{\circ} \mathrm{C}$. temperature that Anderson recorded at a depth of $\mathrm{i} 6 \mathrm{~m}$. througheut the winter of I957. This temperature might be considered to approximate closely the average mean annual temperature of Byrd Station.

Although temperatures have been observed to decrease by less than $0 \cdot 2^{\circ} \mathrm{C}$. from $45 \mathrm{~m}$. to the bottom of the drill hole, there are, nevertheless, some rather significant changes in gradient. These are illustrated in the gradient profile in Figure 2 from data obtained with probe No. 2

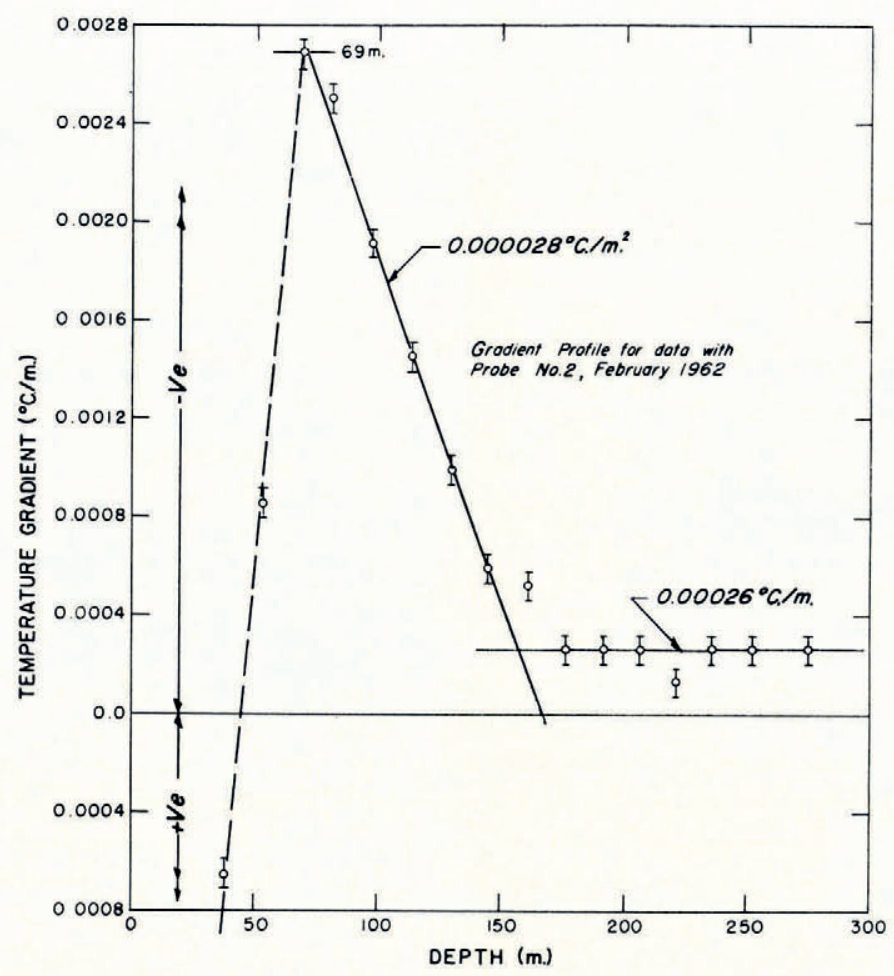

Fig. 2. Temperature gradient profile, Byrd Station deep drill hole

in January 1962. A gradient maximum of $-0.0027^{\circ} \mathrm{C}$. $/ \mathrm{m}$. was observed at a depth of $69 \mathrm{~m}$. and this then decreased linearly with increasing depth at the rate of $0 \cdot 000028^{\circ} \mathrm{C} . / \mathrm{m}$. per meter. If this rate of change of gradient had been maintained beyond $\mathrm{s} 66 \mathrm{~m}$. the temperature profile would have developed a positive gradient below that depth. Instead, the rate of change of gradient begins to fall off just above $150 \mathrm{~m}$., and a constant gradient profile is developed below $170 \mathrm{~m}$. The gradient, $-0 \cdot 00026^{\circ} \mathrm{C} . / \mathrm{m}$. is approximately one order of magnitude smaller than the gradient maximum observed at $69 \mathrm{~m} .\left(-0.0027^{\circ} \mathrm{C} . / \mathrm{m}\right.$.). It is interesting to note that a constant gradient profile was also found to develop at about the same depth in 
the drill hole at Site 2 Greenland (Hansen and Landauer, 1958). At Site 2, however, the gradient of $-0 \cdot \mathrm{oor}^{\circ} \mathrm{C}$. $/ \mathrm{m}$. is nearly four times larger than the gradient observed at Byrd Station. At some point in the $2,400 \mathrm{~m}$. thick ice sheet at Byrd Station temperatures must begin to increase with depth as geothermal and frictional heat sources take effect. Temperature measurements in the upper $300 \mathrm{~m}$. are of little help in this respect, since with the development of a constant gradient profile below $170 \mathrm{~m}$., it is not possible to extrapolate to the depth at which this overturn of temperatures would actually take place. A negative temperature gradient could conceivably persist to a considerable depth in the ice sheet at Byrd Station, and there is an obvious need for temperature measurements to much greater depths than hitherto obtained for the inland ice of Antarctica. This would require the drilling of a hole to at least the depth of temperature overturn and preferably deeper. Until this is done the whole question of temperature distribution in thick ice sheets will remain largely in the realm of speculation.

Temperature in the upper layers of an ice sheet are sensitive to variations at the surface. Profiles exhibiting negative gradients are generally thought to have developed in response to surface warming, due either to climatic amelioration or to the downhill movement of ice from colder to warmer temperatures at the lower elevations. Considering first the effects of ice motion, the magnitude of the gradient can be approximated in terms of Robin's (1955) equation $\frac{d t}{d x}=\frac{\alpha \lambda V}{v}$, where $\frac{d t}{d x}$ is the observed temperature gradient, $\alpha$ the surface slope of the ice sheet, $\lambda$ the rate of change of surface temperature with altitude, $V$ the surface velocity of the ice, and $v$ the rate of ice accumulation at the surface. Now according to Wexler (I96I), the Byrd Station traverse measurements have yielded values of $\alpha=\mathrm{I} \cdot 67 \times \mathrm{IO}^{-3}$, and $\lambda=0.765^{\circ} \mathrm{C}$. $/ 100 \mathrm{~m}$. in the general vicinity of Byrd Station. Assuming a constant rate of accumulation of $0.18 \mathrm{~m}$. of ice per year (Bender and Gow, I96I), it would require a surface movement of about $30 \mathrm{~m}$. $/ \mathrm{yr}$. to account for the $0.36^{\circ} \mathrm{C}$. decrease in temperatures from $15 \mathrm{~m}$. to $\mathrm{I} 70 \mathrm{~m}$. solely in terms of the Robin effect. Measurements of ice velocity at Byrd Station are not yet available, but if the surface movement should turn out to be appreciably smaller than the value computed above then the effect of climatic warming would need to be considered. Mellor (1960), for instance, believes climatic changes are important for he finds that, if negative gradients are to be attributed solely to the Robin effect, then improbably high ice velocities would be needed to explain the temperature gradients observed in East Antarctica. Unfortunately, no reliable data on climatic trends in Antarctica are available at present, but in Greenland there is every indication that climatic warming has contributed to the formation of negative gradients in the upper layers of the ice sheet, as appreciable warming has been observed at a number of localities over the past $50 \mathrm{yr}$. At Site 2 , for example, climatic warming seems to provide the only reasonable explanation of the negative gradient profile observed in the 4 I I $\mathrm{m}$. drill hole, as negligible surface movement has been detected since the camp was established more than seven years ago. The approximate ten-fold increase in gradient above I $70 \mathrm{~m}$. may reflect the climatic factor (warming) superimposed on the persistent thermal effects of ice movement. Until direct observational data on ice flow and climatic trends at Byrd Station become available, it is suggested that both processes may have contributed to the development of the negative temperature gradients observed in the drill hole.

\section{Inclinometer measurements}

Measurements with a Lane-Wells single-shot inclinometer in December $195^{8}$ revealed inclinations of up to 0.5 degree to a depth of $122 \mathrm{~m}$. Negligible inclinations were recorded at all depths below $122 \mathrm{~m}$. In January 1960 , measurements were repeated with a Parsons Survey multiple-shot instrument. Results of this survey are presented in Figure 3. An inclination of 0.3 degree was observed at $\mathrm{I} 8_{3} \mathrm{~m}$. Minor bending was recorded at $\mathrm{I} 22 \mathrm{~m}$. and $244 \mathrm{~m}$., but elsewhere in the drill hole the inclination from the vertical was found to be negligible. 
Identical results were obtained in the resurvey in February 1962, and it is concluded that the drill hole has undergone insignificant bending since it was drilled more than five years ago. This would imply the existence of negligible differential motion in the top $300 \mathrm{~m}$. of the $2,400 \mathrm{~m}$. thick ice sheet at Byrd Station.
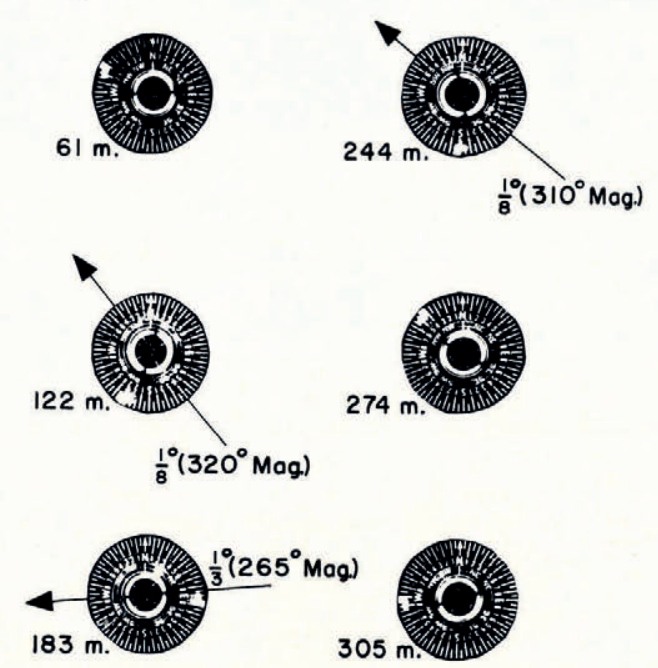

Fig. 3. Inclinometer survey of Byrd Station deep drill hole, January 1960

\section{Hole closure measurements}

Hole diameters were measured at ${ }_{5} 5 \mathrm{~m}$. intervals with a spring-loaded caliper that varies an electrical resistance as a function of the diameter. The diameter $d$ of the drill hole was calculated from the equation

$$
d=2 c+2\left[r\left(\frac{R-R_{\mathrm{o}}}{k}\right)-\left(\frac{R-R_{\mathrm{o}}}{2 k}\right)^{2}\right]^{\frac{1}{2}}
$$

where $c, r$ and $k$ are constants dependent upon the design of the caliper, $R_{\mathrm{o}}$ is the resistance of the caliper in the fully closed position, and $R$ is the resistance measured with the caliper in the drill hole. A short description of this caliper and the derivation of the above equation are given by Hansen and Landauer (1958). The caliper is designed to measure diameters of between $6 \mathrm{~cm}$. and $15 \mathrm{~cm}$. with a limit of error of $0 \cdot 2$ per cent. Sensitivity varies from $0 \cdot \mathrm{I}_{\mathrm{I}}$ per cent at $6 \mathrm{~cm}$. to 0.03 per cent at $15 \mathrm{~cm}$. The results of four years' measurements are presented in Table II and Figure 4. The diameter of the hole measured $14.63 \mathrm{~cm}$. when drilled, but by January I96I the unrestrained bore hole had contracted to less than $6 \cdot 2 \mathrm{~cm}$. at $289 \mathrm{~m}$. Measurements with a $2.5 \mathrm{~cm}$. diameter, lead-filled brass tube attached to a linen fish line showed that the hole had closed off to a diameter of $2.5 \mathrm{~cm}$. at $305 \mathrm{~m}$. depth.

In February 1962 an unstretchable wire line and a set of brass rods ranging in diameter from $5 \cdot \mathrm{I} \mathrm{cm}$. to $\mathrm{I} \cdot 27 \mathrm{~cm}$. were used to obtain accurate measurements of closure near the bottom of the drill hole. These measurements revealed a marked falling off of the closure below $270 \mathrm{~m}$.- - as illustrated in the February 1962 depth-diameter profile in Figure 4. Clearly, some constraint is developing in the bottom section of the drill hole. This constraint could be related to the actual dimensions of crystals of ice in the walls of the drill hole, as crystals as large as $\mathrm{I} \cdot 5 \mathrm{~cm}$. in diameter have been observed in thin sections of cores from the bottom of the drill hole. Once the bore hole had contracted to a size approaching that of the individual crystals in the walls of the drill hole, then some resistance to further closure could be expected to develop. At least it would seem, in the deepest parts of the drill hole anyway, that the actual size of the hole (and possibly the shape) is now exerting an increasing effect on the closure. 
Table II. Deep Hole Diameter Measurements, Byrd Station, 1958-62

\begin{tabular}{|c|c|c|c|c|c|}
\hline $\begin{array}{c}\text { Depth } \\
\text { m. }\end{array}$ & $\begin{array}{c}\text { Load } \\
\text { Pressure } \\
\text { kg./cm. }{ }^{2}\end{array}$ & $\begin{array}{c}\text { Diameter } \\
\text { December }{ }^{195^{8}} \\
\mathrm{~cm} .\end{array}$ & $\begin{array}{c}\text { Diameter } \\
\text { fanuary } 1960 \\
\mathrm{~cm} .\end{array}$ & $\begin{array}{c}\text { Diameter } \\
\text { fanuary } 196 I \\
\mathrm{~cm} .\end{array}$ & $\begin{array}{c}\text { Diameter } \\
\text { February } 1962 \\
\text { cm. }\end{array}$ \\
\hline $\begin{array}{l}15 \\
31 \\
46 \\
61 \\
76\end{array}$ & $\begin{array}{l}0 \cdot 75 \\
1 \cdot 77 \\
2 \cdot 85 \\
4 \cdot 04 \\
5 \cdot 32\end{array}$ & $\begin{array}{l}15 \cdot 34 \\
15 \cdot 34 \\
14 \cdot 71 \\
14 \cdot 63 \\
14 \cdot 61\end{array}$ & $\begin{array}{l}15 \cdot 42 \\
15 \cdot 42 \\
14.71 \\
14.68 \\
14.63\end{array}$ & $\begin{array}{l}15.39 \\
15.39 \\
14.55 \\
14.61 \\
14.48\end{array}$ & $\begin{array}{l}\text { I } 5 \cdot 39 \\
\text { I } 5 \cdot 42 \\
\text { I } 4 \cdot 60 \\
\text { I } 4 \cdot 55 \\
\text { I } 4 \cdot 45\end{array}$ \\
\hline $\begin{array}{r}91 \\
106 \\
122 \\
137 \\
152\end{array}$ & $\begin{array}{r}6 \cdot 63 \\
7 \cdot 98 \\
9 \cdot 34 \\
10 \cdot 80 \\
12 \cdot 16\end{array}$ & $\begin{array}{l}14 \cdot 58 \\
14 \cdot 58 \\
14 \cdot 45 \\
14 \cdot 45 \\
14 \cdot 43\end{array}$ & $\begin{array}{l}14 \cdot 5 \mathrm{I} \\
14 \cdot 45 \\
14 \cdot 38 \\
14 \cdot 35 \\
14 \cdot 15\end{array}$ & $\begin{array}{l}14 \cdot 43 \\
14 \cdot 33 \\
14 \cdot 20 \\
14 \cdot 05 \\
13 \cdot 82\end{array}$ & $\begin{array}{l}14 \cdot 41 \\
14 \cdot 33 \\
14 \cdot 10 \\
13 \cdot 89 \\
13 \cdot 54\end{array}$ \\
\hline $\begin{array}{l}168 \\
183 \\
198 \\
213 \\
228\end{array}$ & $\begin{array}{l}13 \cdot 63 \\
15 \cdot 00 \\
16 \cdot 37 \\
17 \cdot 74 \\
19 \cdot 12\end{array}$ & $\begin{array}{l}14 \cdot 35 \\
14 \cdot 25 \\
14 \cdot 12 \\
14 \cdot 00 \\
13 \cdot 82\end{array}$ & $\begin{array}{l}13 \cdot 92 \\
13 \cdot 74 \\
13 \cdot 41 \\
13 \cdot 06 \\
12 \cdot 65\end{array}$ & $\begin{array}{l}13 \cdot 54 \\
13 \cdot 18 \\
12 \cdot 65 \\
12 \cdot 04 \\
11 \cdot 25\end{array}$ & $\begin{array}{r}13 \cdot 06 \\
\text { I } 2 \cdot 40 \\
\text { I1 } \cdot 79 \\
\text { I0 } \cdot 74 \\
9 \cdot 45\end{array}$ \\
\hline $\begin{array}{l}244 \\
259 \\
274\end{array}$ & $\begin{array}{l}20 \cdot 5^{8} \\
21 \cdot 96 \\
23 \cdot 35\end{array}$ & $\begin{array}{l}13.67 \\
13.41 \\
12.83\end{array}$ & $\begin{array}{l}12 \cdot 04 \\
11 \cdot 30 \\
10 \cdot 80\end{array}$ & $\begin{array}{r}10 \cdot 21 \\
9 \cdot 19 \\
8 \cdot 10\end{array}$ & $\begin{array}{l}8 \cdot 3 \mathrm{I} \\
6 \cdot \mathrm{I} 5 \\
5 \cdot 08(262 \mathrm{~m} .) \\
3 \cdot 8 \mathrm{I}(269 \mathrm{~m} .)\end{array}$ \\
\hline $\begin{array}{l}289 \\
305\end{array}$ & $\begin{array}{l}24 \cdot 73 \\
26 \cdot 17\end{array}$ & $\begin{array}{l}12 \cdot 70 \\
12 \cdot 14\end{array}$ & $\begin{array}{l}9 \cdot 68 \\
8 \cdot 3 \mathrm{I}\end{array}$ & $\begin{array}{l}6 \cdot 20 \\
2 \cdot 50\end{array}$ & $\begin{array}{l}2.54(278 \mathrm{~m} .) \\
\mathrm{I} \cdot 27(296 \mathrm{~m} .)\end{array}$ \\
\hline
\end{tabular}

In Figure 5, hole closures at various depths in the drill hole have been plotted against time. The resultant family of curves shows that deformation rates have increased steadily at all depths, with the most rapid increases taking place in the deeper parts of the drill hole. Of considerable interest though, is the definite fall off of closure rates after the hole has contracted to a diameter of about $3.0 \mathrm{~cm}$. This behavior was first observed in the lowermost $30 \mathrm{~m}$. of the drill hole at the end of $4 \mathrm{yr}$. closure. As already noted this may reflect the attainment of a critical close-off diameter, beyond which the physical dimensions of crystals in the walls of the drill hole act to retard the closure. A similar pattern of closure has also been observed in the 4 I I m. bore hole at Site 2 Greenland. At Site 2, however, the first year's deformation was approximately $70-80$ per cent greater than that observed in the Byrd Station drill hole. Since this significantly greater closure at Site 2 can most likely be attributed to warmer temperatures in the ice at Site 2, we might write:

$$
\frac{\dot{\epsilon}_{\mathrm{I}}}{\dot{\epsilon}_{2}}=\exp \left[-\frac{E}{R}\left(\frac{\mathrm{I}}{T_{\mathrm{I}}}-\frac{\mathrm{I}}{T_{2}}\right)\right]
$$

where $\dot{\epsilon}_{\mathrm{I}}$ and $\dot{\epsilon}_{2}$ are the strain closure rates at comparable overburden pressures in the unrestrained drill holes at Byrd Station and Site 2, respectively, $T_{\mathrm{I}}$ and $T_{2}$ the corresponding drill hole temperatures in degrees absolute, $E$ the energy of activation and $R$ the gas constant. Accordingly,

$$
0.59=\exp \left[-\frac{E}{\mathrm{I} \cdot 9^{8}}\left(\frac{3 \cdot 2}{244 \cdot 6 \times 247 \cdot 8}\right)\right]
$$

from which, $E$ turns out to be $19.8 \mathrm{kcal}$./mole. This is somewhat higher than the generally accepted value of $14 \mathrm{kcal}$./mole for ice, but it is close to the value of $18.7 \mathrm{kcal} . / \mathrm{mole}$ that Nakaya (1959) derived from visco-elastic measurements of old ice-sheet ice from Greenland. In this evaluation of the activation energy it was assumed that the rate of deformation $(\dot{\epsilon})$ could be expressed in an equation of the form $\dot{\epsilon}=A \exp (E / R T) \sigma^{n}$ where $\sigma$ is the applied stress and $A$ and $n$ are constants. This dependence of the strain rate on both the magnitude of the stress and the temperature has been quite clearly established in a number of laboratory tests. In addition, the flow rate is also known to be influenced by the physical condition of the ice, particularly its crystal structure. At Byrd Station the crystal structure variations with depth and other depth-(time-) dependent properties have been analyzed in some detail from 
cores. It might be of interest at this point to give a brief description of these and other properties related to deformation in the drill hole, before discussing the overburden pressure-closure rate relationships in the unrestrained, vertically drilled bore hole at Byrd Station.

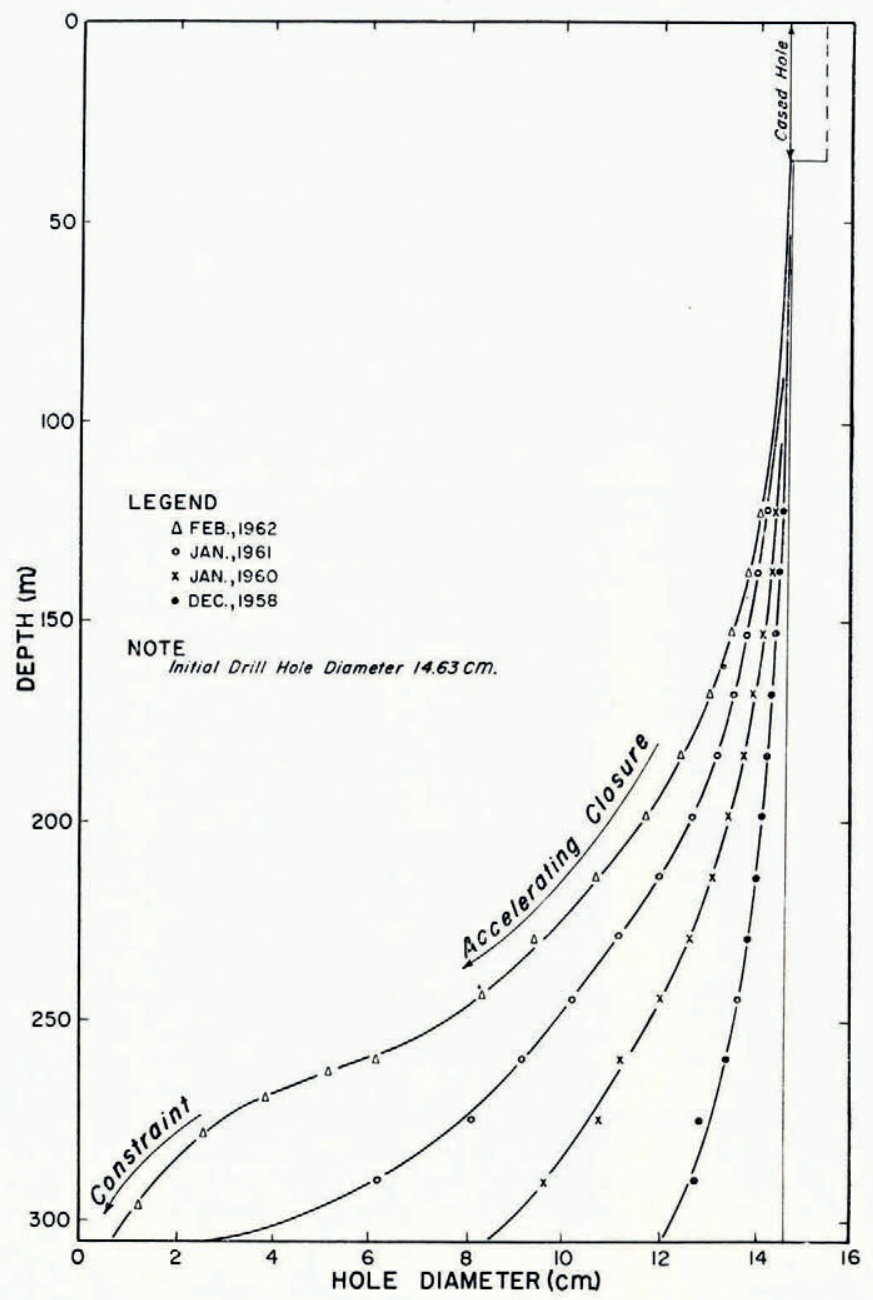

Fig. 4. Depth-diameter profiles, Byrd Station deep drill hole

At Byrd Station the firn transforms into ice at a depth of about $65 \mathrm{~m}$. At this depth pockets of air trapped between firn grains seal off to form individual bubbles; the aggregate is no longer permeable and is, by definition, ice. The density at the firn-ice transition is about $0.830 \mathrm{~g} . / \mathrm{cm} .{ }^{3}$. At $100 \mathrm{~m}$. the ice has attained a density of $0.900 \mathrm{~g} . / \mathrm{cm} .{ }^{3}$, increasing very slowly to $0.916 \mathrm{~g} . / \mathrm{cm} .^{3}$ at $309 \mathrm{~m}$. in cores from the bottom of the drill hole. The density distribution was determined very accurately over the entire length of core, thus facilitating accurate calculation of the overburden pressure at any depth in the drill hole. From additional studies on the ice cores it was found that grain size increased progressively with depth, grain shapes became more irregular, and air bubble pressures increased steadily with increasing depth of burial. The nature and extent of these changes with increasing depth in the ice sheet are illustrated in the thin-section photographs and petrofabric diagrams in Figure 6. Ice at $7 \mathrm{I}$. from just below the firn-ice transition is composed of equidimensional crystals - a 
mosaic texture--with tubular bubbles of entrapped air concentrated at the intersections of crystals rather than along the crystal boundaries. Ice from a depth of ${ }_{1} 63 \mathrm{~m}$. shows obvious signs of grain growth, with air bubbles now largely located within the boundaries of individual crystals. Interlocked crystals of irregular outline, some exhibiting undulatory extinction, and all enclosing spherical bubbles of highly compressed air, characterize the texture of polycrystalline ice from $305 \mathrm{~m}$. depth. Despite these marked changes in the size and shape of crystals with depth (an approximate ten-fold increase in the average crystal cross-sectional area between $7 \mathrm{I} \mathrm{m}$. and $305 \mathrm{~m}$.), petrofabric studies revealed only weak patterns of preferred orientation of crystallographic $c$-axes. Since shear seems essential to the formation of oriented

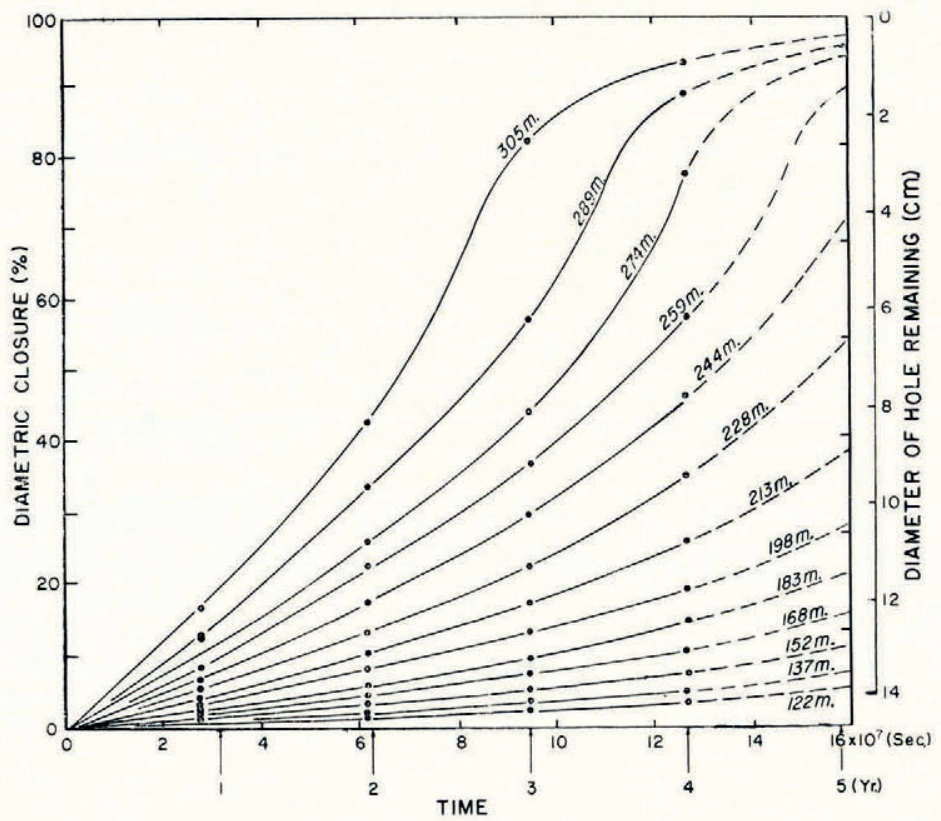

Fig. 5. Variations in deformation rates with depth in the drill hole at Byrd Station. Deformation (diametric closure) $=\left(D_{0}-D_{t}\right) / D_{0}$ where $D_{0}=I 4.63 \mathrm{~cm}$.

fabrics in ice we might conclude that little shear exists in the top $300 \mathrm{~m}$. of the ice sheet at Byrd Station. As already noted englacial temperatures were observed to decrease by less than $0 \cdot 2^{\circ} \mathrm{C}$. between $70 \mathrm{~m}$. and the bottom of the drill hole, so that drill hole closure can be considered to have occurred under constant temperature conditions. In the absence of any significant bending of the drill hole it is assumed that the walls of the unrestrained bore hole are squeezing inwards solely in response to the overburden pressures. Since contraction can be considered to take place only in the radial direction, the drill hole should deform symmetrically, i.e. the hole should retain its circular shape during closure. This has not been specifically determined, but experiments by Higashi (1959) on the plastic deformation of thick-walled snow-ice cylinders under high hydrostatic pressure have shown that the cylindrical cavities do in fact maintain their circular shape during deformation. It is most unlikely that hoar-frost accretion could have contributed to drill hole closure. Measurements in the $36 \mathrm{~m}$. section of drill casing have revealed no changes whatsoever in its internal diameter since its emplacement in January 1958, and there is no reason to suspect any reduction of diameter by deposition of hoar-frost on the walls of the uncased drill hole either. However, a natural relaxation of ice in the walls of the drill hole, may have contributed to the closure. Langway (1958) has shown that glacier ice with bubble pressures exceeding about 10 atmospheres will relax when removed 
from its confining environment. It is possible that a sufficient relief of stress could occur in the deepest parts of the drill hole (below $150 \mathrm{~m}$.) to allow bubbles of entrapped air to expand and cause a subsequent increase in the specific volume of the ice in the walls of the drill hole. Superficial cracks may even develop on the walls, but the overall effect on closure is probably very small in comparison with the true plastic contraction of the drill hole.
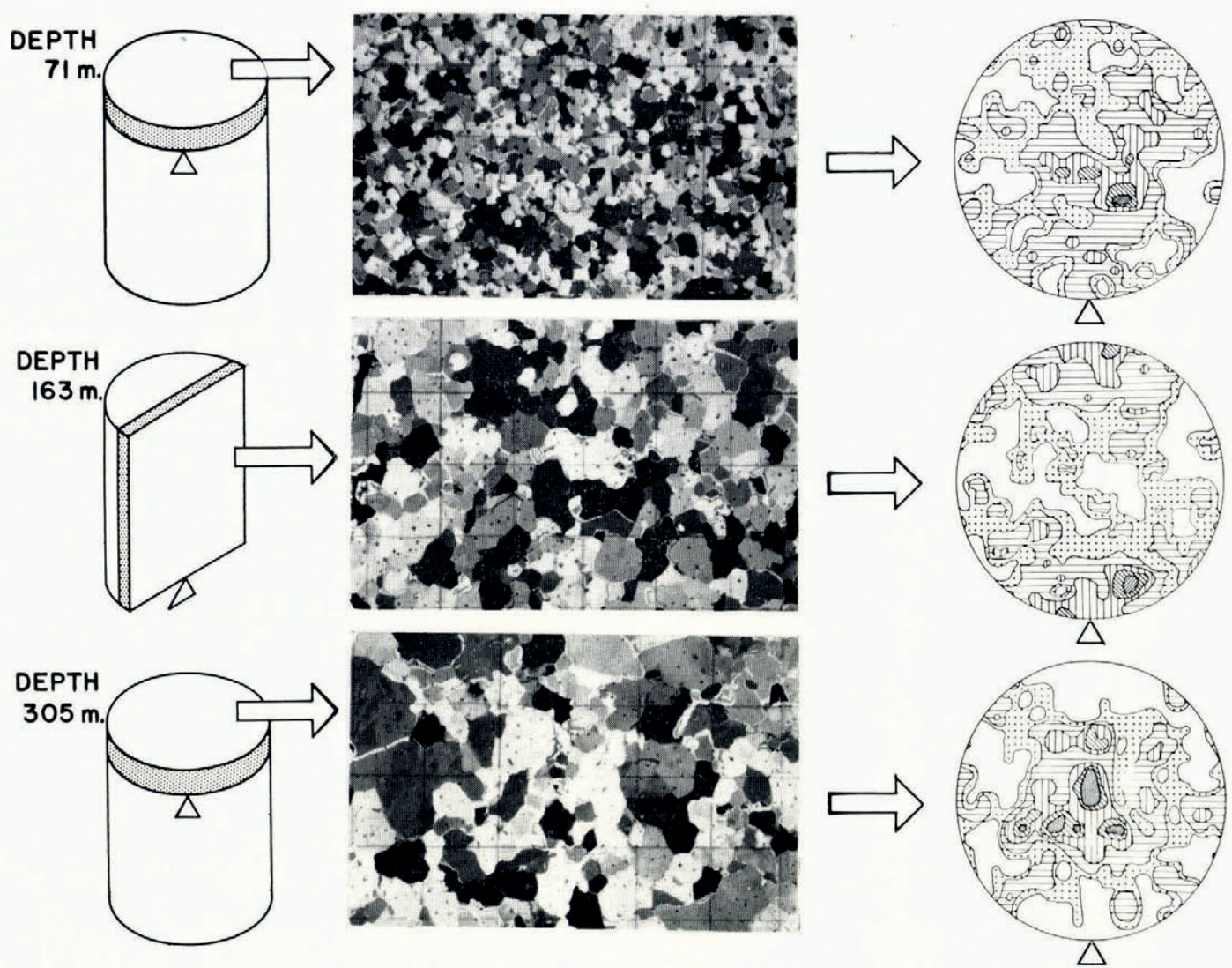

Fig. 6. Crystal structures and ice fabrics in cores from deep drill hole, Byrd Station, Antarctica. Contours at $4 \%, 3 \%, 2 \%, 1 \%$, $0.5 \%$ per $1 \%$ area in c-axes orientation diagrams. Lines on thin sections represent $1 \mathrm{~cm}$. grid

Now according to Nye (1953) the rate of contraction of a vertical cylindrical hole in ice can be expressed in a relationship of the form $S=(\sigma / n A)^{n}$ where $S$ is the rate of contraction, $\sigma$ is the hydrostatic stress at some sufficient horizontal distance from the drill hole, and $A$ and $n$ are constants. This constitutes the simple power-law relationship between stress and strainrate for steady-state creep in ice. From the large number of experimental determinations of $n$ where the minimum creep rate has been observed, the value of $n$ has been found to vary between I and 4 depending on the stress. If closure in the drill hole at Byrd Station were to conform to steady state creep, then the rates of closure should remain constant and the hole should never close off. However, measurements over a period of four years show that closure has been accelerating. Double logarithmic plots of closure rate versus load pressure are presented in Figure 7 to give some idea of this departure from constant power-law behavior. In these the logarithms of the ratios of the diameter at the beginning and after exactly one year's closure have been used to approximate the strain-rates. The time-deformation curves in Figure 5 were used to determine hole diameters after exactly one, two, three, and four years' 
closure. A reasonably straight line of slope 3 - I can be fitted to the first year's results, but data for the next three years deviate considerably from lines of constant slope. A very approximate straight line fit for data from the fourth year's measurements gives an $n$ value of about $6 \cdot 0$. Clearly the strain (closure) rate is not proportional to some constant power of the stress but increases with increasing stress. Some of Glen's laboratory tests suggest similar behavior (Glen, I955) and the results of Butkovich and Landauer (1958), Hansen and Landauer ( $95^{8}$ ), Higashi (1959) and Jellinek (1960) and others on the plastic deformation of ice under a variety of stresses all show the same tendency for creep to accelerate at the higher stresses. An additional feature of Figure 7 is the very definite increase in the closure rates with time,

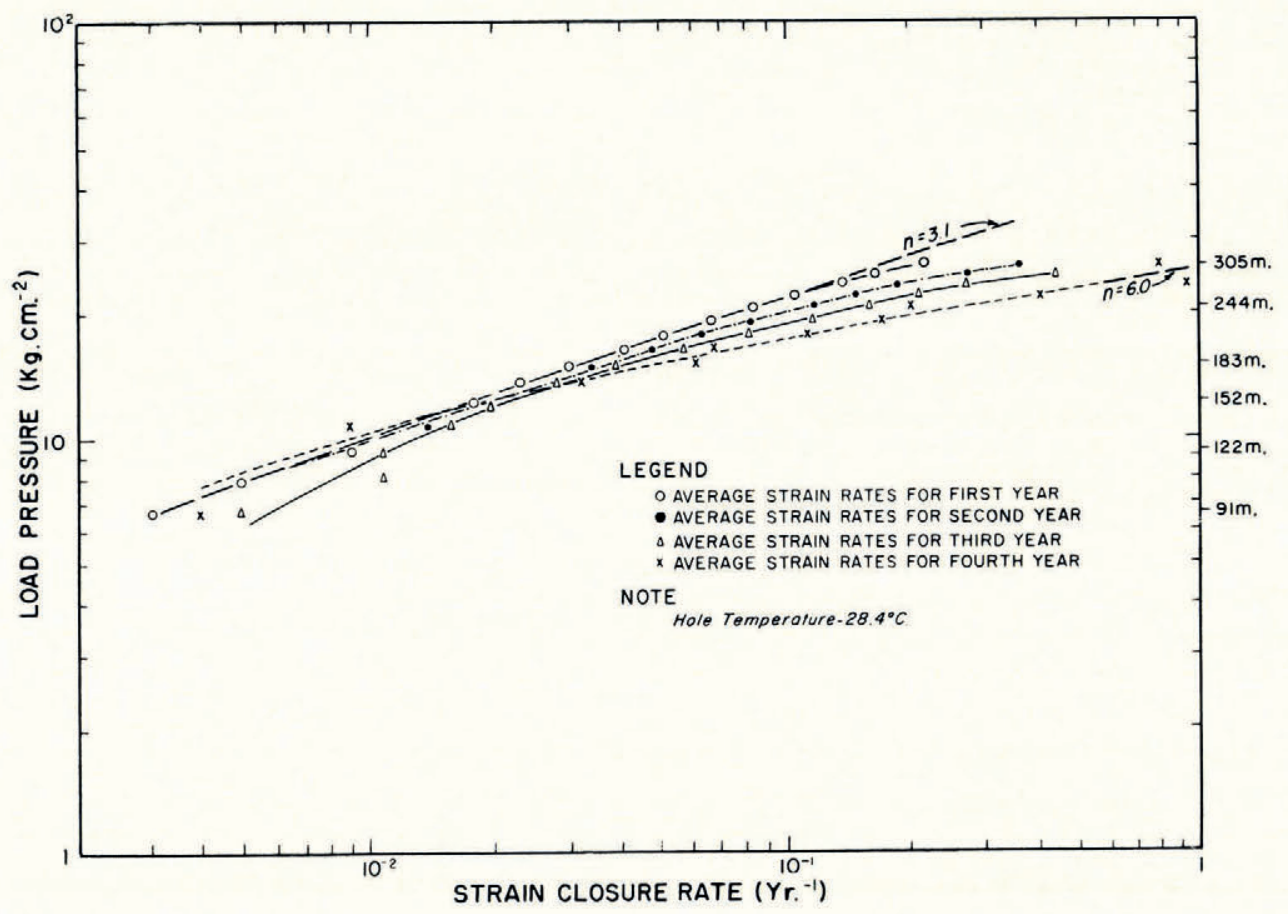

Fig. 7. Deep hole strain (closure) rates versus overburden pressure at Byrd Station

even at the lower overburden pressures. This would imply that the rate of contraction of the bore hole depends not only on the magnitude of the overburden pressure, but also on the time for which the pressure is applied. With time we can associate the possible effects of recrystallization, and deviations from ideal power law behavior can perhaps be best explained in terms of the changes in the physical condition of the ice as it deforms. Glen (1958), for example, has attributed accelerating flow in laboratory-deformed polycrystalline ice to the recrystallization of ice to a preferred orientation favorable to gliding, and there is abundant evidence from the field (see Rigsby, 1958) to show that recrystallization and reorientation of individual crystals into positions facilitating gliding contribute significantly to flow in glaciers-bodies of naturally deforming polycrystalline ice. Just how strain-induced recrystallization (if any) has affected the original structure of the ice in the walls of the drill hole at Byrd Station is impossible to determine at this stage. Actual granulation of crystals at high stress or some process of crystal boundary migration with or without intracrystalline gliding might be involved, but it does seem necessary at this stage to invoke some process of continuous recrystallization (parakinematic crystallization) involving strain-softening of the ice to account for the accelerating closure in the Byrd Station drill hole. 
It would be extremely interesting to obtain samples of wall ice for determining the mode and extent of any recrystallization at various depths in the drill hole. Of particular interest would be those samples from near the bottom of the hole where the greatest deformation has occurred. Unfortunately these are the very depths at which maximum contraction has occurred, and where sampling would be the most difficult. Perhaps the simplest, and certainly the most effective method of sampling would be to redrill the old hole. Apart from providing samples of deformed ice for comparison with undeformed ice from the original drilling, the recored material would also furnish direct evident of the size and shape of the deformed drill hole at various stages of its contraction. These cores, of course, would provide indisputable proof of whether or not the drill hole had retained its cylindrical shape during closure. In addition, such a redrilling would restore the old hole to its original diameter, thereby permitting further measurements of closure. These measurements could prove significant in that any extensive recrystallization from the previous deformation could be expected to exert considerable influence on deformation in the redrilled borehole. If measurements were found more or less to duplicate the previous results (say, at the end of two years) then the hole could be piped and used for long-term measurements of inclination. The drill casing, if extended periodically above the snow surface to keep pace with the accumulation, would serve as a permanent marker for measuring surface movement of the ice sheet at Byrd Station. Redrilling is a thoroughly feasible operation and could be accomplished with the same rig used in the original drilling in $1957-5$. In view of the results already obtained, and for the reasons outlined above, a recoring project is strongly advocated.

\section{Acknowledgements}

This work was conducted while the author was employed with the Arctic Institute of North America, and latterly as a member of the Materials Research Branch of the U.S. Army Cold Regions Research and Engineering Laboratory. The project was sponsored by the U.S. National Committee of the I.G.Y. and the office of the U.S. Antarctic Research Programs and supported by the National Science Foundation. The co-operation of these organizations is gratefully acknowledged. Thanks are due also to various colleagues and the U.S. Navy for their invaluable support in the field. In particular the author is indebted to R. W. Patenaude and J. V. Tedrow for their masterful drilling of the deep hole at Byrd Station and to B. Lyle Hansen who supervised the design and calibration of the measuring equipment.

MS. received 5 May 1963

\section{REFERENCES} Anderson, V. H. 1958. Byrd station glaciological data. Ohio State University Research Foundation. Report $825-1-$
Part II.

Bender, J. A., and Gow, A. J. 1961. Deep drilling in Antarctica. Union Géodésique et Géophysique Internationale. Association Internationale d'Hydrologie Scientifique. Assemblée générale de Helsinki, 25-7-6-8 196o. Colloque sur la glaciologie antarctique, p. $132-4 \mathrm{I}$.

Butkovich, T. R., and Landauer, J. K. 1958. The flow law for ice. Union Géodésique et Géophysique Internationale. Association Internationale d'Hydrologie Scientifique. Symposium de Chamonix, 16-24 sept. 1958, p. 318-27. Glen, J. W. ${ }^{1} 955$. The creep of polycrystalline ice. Proceedings of the Royal Society, Ser. A, Vol. 228, No. I I 75 ,
p. 519-38.

Glen, J. W. ${ }^{1958}$. The flow law of ice: a discussion of the assumptions made in glacier theory, their experimental foundations and consequences. Union Géodésique et Géophysique Internationale. Association Internationale d'Hydrologie Scientifique. Symposium de Chamonix, $16-24$ sept. 1958 , p. $17 \mathrm{I}-8_{3}$.

Hansen, B. L., and Landauer, J. K. 1958. Some results of ice cap drill hole measurements. Union Géodésique et Géophysique Internationale. Association Internationale d'Hydrologie Scientifique. Symposium de Chamonix, I6-24 sept. 1958 , p. $3^{1} 3^{-1} 7$

Higashi, A. 1959. Plastic deformation of hollow ice cylinders under hydrostatic pressure. U.S. Snow, Ice and Permafrost Research Establishment. Research Report $5 \mathrm{I}$.

Jellinek, H. H. G. I96o. Plastic deformation of thick-walled snow-ice cylinders under hydrostatic pressure. U.S. Snow, Ice and Permafrost Research Establishment. Research Report 63. 
Lange, G. R. In press. Deep rotary core drilling in ice. U.S. Cold Regions Research and Engineering Laboratory. Technical Report 94.

Langway, C. C., jr. 1958. Bubble pressures in Greenland glacier ice. Union Géodésique et Géophysique Internationale. Association Internationale d'Hydrologie Scientifique. Symposium de Chamonix, I6-24 sept. 1958, p. 336-49.

Marshall, E. W., and Gow, A. J. I958. Core drilling in ice, Byrd station, Antarctica. Part II: core examination and drill hole temperatures. IGY Glaciological Report Series (New York, IGY World Data Center A, Glaciology, American Geographical Society), No. I, p. V-6-ro.

Mellor, M. 1960. Temperature gradients in the Antarctic Ice Sheet. Fournal of Glaciology, Vol. 3, No. 28 , p. $773-82$.

Nakaya, U. 1959. Visco-elastic properties of snow and ice in the Greenland Ice Cap. U.S. Snow, Ice and Permafrost Research Establishment. Research Report 46.

Nye, J. F. I953. The flow law of ice from measurements in glacier tunnels, laboratory experiments and the Jungfraufirn borehole experiment. Proceedings of the Royal Society, Ser. A, Vol. 219, No. 1139, p. 477-89.

Patenaude, R. W. 1958. Core drilling in ice, Byrd station, Antarctica. Part I: drilling techniques. IGY Glaciological Report Series (New York, IGY World Data Center A, Glaciology, American Geographical Society), No. I, p. V-1-5.

Ragle, R. H., and others. I96o. Deep core drilling in the Ross Ice Shelf, Little America V, Antarctica, by R. H. Ragle, B. L. Hansen, A. J. Gow and R. W. Patenaude. U.S. Snow, Ice and Permafrost Research Establishment. Technical Report 70.

Rigsby, G. P. 1958. Fabrics of glacier and laboratory deformed ice. Union Géodésique et Géophysique Internationale. Association Internationale d'Hydrologie Scientifique. Symposium de Chamonix, ${ }_{1} 6-24$ sept. 1958 , p. $35^{1-58}$.

Robin, G. de Q. 1955. Ice movement and temperature distribution in glaciers and ice sheets. Journal of Glaciology, Vol. 2, No. 18, p. 523-32.

Wexler, H. I961. Growth and thermal structure of the deep ice in Byrd Land, Antarctica. Journal of Glaciolcgy, Vol. 3, No. 30, p. $1075^{-87}$. 